Nordisk Tidsskrift for Kriminalvidenskab 2007

KRIMINALITETSREJSEN

OM INDBRUDSTYVES MOBILITET

Af FORSKNINGSLEKTOR, PH.D. DAVID WM SORENSEN

This article describes the Danish journey to residential burglary, i.e., the distance that burglars travel between their homes and their burglary targets. It is based on an analysis of 3,238 crime trips made by offenders throughout Denmark during the 20-month period 1 January 2002 to 31 August 2003. The Danish data support all of the primary findings of previous international research, specifically: (1) that the majority of crime trips are short; (2) that the number of crimes committed decreases with distance from offenders' residences ("distance decay"); and (3) that there is a "buffer zone" immediately surrounding offenders' homes within which they avoid committing crime - presumably out of concern for being recognized. The current study is unique in terms of the size and quality of the crime trip data available for analysis. Furthermore, it advances prior research by distinguishing trips to different types of residential targets (e.g., stand-alone houses; apartments; farm houses; etc.). The article concludes with an analysis of the popular assumption that burglars favor affluent areas when seeking crime targets - an assumption that is not supported by the data.*

\title{
Indledning
}

Hvor langt bevæger en indbrudstyv sig for at begå kriminalitet? I hvilken udstrækning er rejseafstanden afhængig af gerningsstedets karakter? Rejser indbrudstyve typisk fra socialt dårligt stillede områder til velhaverområder i deres søgen efter lukrative mål? Det er spørgsmål, som belyses i denne artikel, der er baseret på en undersøgelse af indbrudstyveri i beboelser m.v. i Danmark. ${ }^{1}$

Udtrykket "journey to crime" - kriminalitetsrejsen - angår afstanden mellem lovovertræderens bopæl og gerningsstedet. Udtrykket har været kendt $\mathrm{i}$ den kriminologiske forskning i omkring 30 år, men undersøgelser af fænomenet går længere tilbage i tiden. Whites banebrydende undersøgelse, der viste, at de fleste kriminalitetsrejser er relativt korte, og at de varierer med kriminalitetens art, er således fra 1932.

Forskningen i rejseafstande i forbindelse med kriminalitet er karakteriseret ved fire vigtige resultater, som er påvist $i$ alle større studier:

\footnotetext{
* Title in English: The Journey to Crime: On the Mobility of Residential Burglars. Original in Danish.
} 
(1) Størstedelen af kriminalitetsrejserne er relativt korte. Adskillige studier har vist, at mere end 50 pct. af såvel berigelses- som voldskriminaliteten har fundet sted inden for en afstand af $2 \mathrm{~km}$. fra gerningsmandens bopæl (se fx Baldwin and Bottoms 1976; Repetto 1974; Pope 1980). Dette mønster er antagelig et resultat af (a) en simpel cost-benefit kalkule, hvor kortere ture generelt anses for at være mindre krævende og derfor at foretrække frem for længere ture, og (b) grænserne for den typiske gerningsmands "fortrolighedsrum" - dvs. de områder omkring gerningsmandens hjem, arbejdsplads, fritidsaktiviteter m.v., som vedkommende kender til og er fortrolig med (Brantingham and Brantingham 1981).

(2) Antallet af begåede forbrydelser aftager med afstanden fra gerningsmandens bopæl. Dette fænomen kaldes "distance decay" (afstandsreduktion) og er ikke kun almindeligt for kriminalitet, men også for andre forhold, der kræver rumlige bevægelser (eksempelvis indkøb og fritidsaktiviteter) (ibid.).

(3) Der er et afgrænset område, en bufferzone, omkring gerningsmandens bopæl, inden for hvilken vedkommende undgår at begå eller forholdsvis sjældent begår kriminalitet - formentlig på grund af risikoen for at blive genkendt.

(4) Rejseafstande til voldskriminalitet (voldtægt, overfald og mord) har en tendens til at være kortere end rejseafstande til berigelseskriminalitet (White 1932; Pyle 1974; Baldwin and Bottoms 1976). Forskellen skyldes formentlig det faktum, at noninstrumentel kriminalitet, som den meste vold må betegnes som, med større sandsynlighed end berigelseskriminalitet vil forekomme spontant og derfor også ske i de områder, hvor personen har sine sædvanlige daglige aktiviteter, dvs. i en zone omkring hjemmet, bufferzonen. Dertil kommer, at visse former for vold - herunder hustruvold - med meget stor sandsynlighed forekommer i selve hjemmet.

\section{Data og metode}

Det datamateriale, undersøgelsen er baseret på, stammer fra to kilder:

1. Fra det danske politis POLMAP-database, som stammer fra POLSAS (politiets sagsstyringssystem), der er et integreret sagsstyringssystem. ${ }^{2}$ POLMAP-data, der er af exceptionel høj kvalitet, findes i en central national database. Mens de fleste af de tidligere internationale studier angår kriminalitetsrejser inden for enkelte politidistrikter, nabolag eller byer, så giver POLMAP altså mulighed for at undersøge fænomenet på landsplan. 
2. Fra Danmarks Statistik, som har bidraget med oplysninger om boligtæthed og den gennemsnitlige husstandsindkomst inden for postnummerzoner, jf. det senere.

Studien omfatter oplysninger om:

- 3238 indbrudstyverier,

- $\quad$ som alle er resulteret $i$ en sigtelse

- for indbrud eller forsøg på indbrud, begået i perioden fra 1. januar 2002 til 31. august 2003

- mod seks forskellige typer beboelsesejendomme:

○ villaer, inklusiv rækkehuse

- lejligheder

- landejendomme

- fritidshuse, inklusiv kolonihavehuse.

- garager og udhuse (der primært forefindes i forbindelse med villaer)

○ kældre, lofter og pulterrum (der primært forefindes i forbindelse med lejligheder), og

- hvor der er registreret en adresse for både den formodede gerningsmand (den sigtede) og gerningsstedet.

I undersøgelsen måles den euklidiske afstand mellem adressekoordinater for indbrudstyvens og offerets bopæl/gerningsstedet. Euklidisk afstand svarer til fugleflugtslinjen, altså den korteste afstand mellem to punkter.

Tabel 1 viser fordelingen af indbrudstyverier efter gerningsstedets art. Undersøgelsen domineres af indbrudstyverier i villaer og i fritidshuse, som sammenlagt udgør knap fire femtedele af de analyserede kriminalitetsrejser. Kun godt en tiendedel af rejserne angår forsøg på indbrud, hvilket delvist kan tilskrives det faktum, at forsøg sjældnere end fuldbyrdede indbrud anmeldes til politiet og videre sjældnere opklares.

Undersøgelsen omfatter forholdsvis få kvindelige lovovertrædere, nemlig 3 pct.. Fem pct. af lovovertræderne er fremmede statsborgere. Aldersmæssigt er lovovertræderne fra 15 til 67 år med en median på 22. Det er almindeligt med medskyldige, idet der i gennemsnit har været 1,8 lovovertrædere per indbrud.

I godt og vel halvdelen (54 pct.) af tilfældene befinder lovovertræderens bopæl og gerningsstedet sig i forskellige postnummerzoner. ${ }^{3}$ Den del af analysen, der angår forskelle mellem de postnummerzoner, lovovertræder og offer bor inden for, vil alene inkludere denne del af det samlede materiale, nemlig $i$ alt 1705 indbrudstyverier eller rejseafstande. 


\section{Kriminalitetsrejsernes fordeling}

Som vist i tabel 1, er den gennemsnitlige tilbagelagte afstand fra lovovertræderens bopæl til gerningsstedet $14 \mathrm{~km}$. med en median på kun $4,7 \mathrm{~km}$., hvilket indikerer en ekstrem skæv fordeling med få meget store afstande. Den længste kriminalitetsrejse var på næsten $279 \mathrm{~km}$.

Tabel 1. Kriminalitetsrejsernes fordeling efter gerningsstedets art samt afstand.

\begin{tabular}{|l|r|r|r|r|r|r|}
\hline & Antal sager & Pct. & $\begin{array}{c}\text { Minimum } \\
(\mathrm{km} .)\end{array}$ & $\begin{array}{c}\text { Maksimum } \\
(\mathrm{km} .)\end{array}$ & $\begin{array}{c}\text { Gennem- } \\
\text { snit }(\mathrm{km} .)\end{array}$ & $\begin{array}{c}\text { Median } \\
(\mathrm{km} .)\end{array}$ \\
\hline Villaer & 1998 & $62 \%$ & 0 & 271,9 & 13,4 & 3,5 \\
\hline Lejligheder & 279 & $9 \%$ & 0 & 183,2 & 7,5 & 1,3 \\
\hline Landejendom & 159 & $5 \%$ & 0 & 191,9 & 23,7 & 10,6 \\
\hline Fritidshuse & 571 & $17 \%$ & 0,3 & 278,9 & 18,8 & 13,3 \\
\hline Garager/udhus & 134 & $4 \%$ & 0 & 104,3 & 10,7 & 5,8 \\
\hline Kældre/lofter & 97 & $3 \%$ & 0 & 4,9 & 4,9 & 1,0 \\
\hline Alle beboelser & 3238 & $100 \%$ & 0 & 279,0 & 14,0 & 4,7 \\
\hline
\end{tabular}

Figurerne 1a til 1c illustrerer afstanden til indbrud i beboelser (alle typer) på tre forskellige niveauer, hvor der fokuseres på mindre og mindre segmenter af fordelingen. I alle disse og de følgende figurer er skalaenheden $0,5 \mathrm{~km}$.

Figur 1a. Alle kriminalitetsrejser fordelt efter afstand $i \mathrm{~km} . N=3238$.

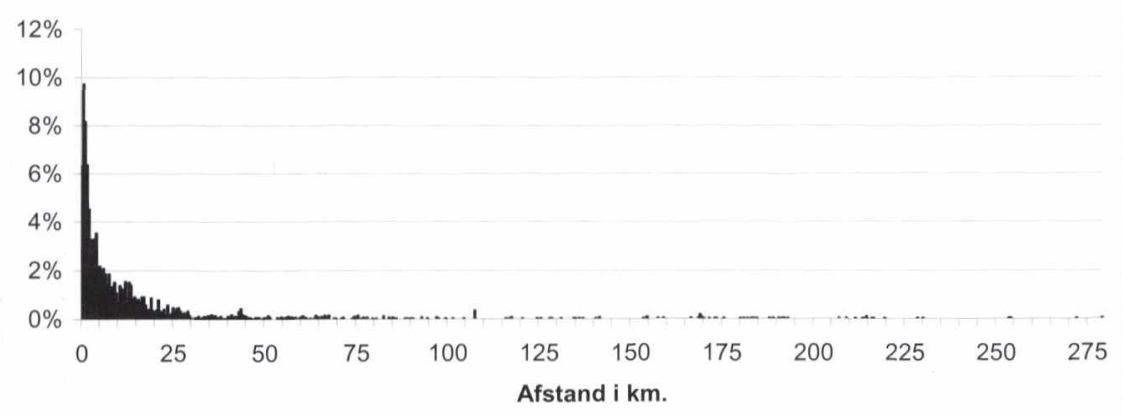

Figur 1a, som afbilleder den fulde fordeling af kriminalitetsrejserne - fra 0 til $278,9 \mathrm{~km}$. - viser, hvor skæv den overordnede fordeling er. Den er så skæv, at det ikke giver mening at vise den fulde fordeling, idet figuren næsten ikke giver nogen visuel information om de længste rejser og efterlader den venstre side for uklar til at kunne bruges. 
Figur 1b. Kriminalitetsrejser op til $50 \mathrm{~km}$. fordelt efter afstand $i \mathrm{~km}$. $N=3047$.

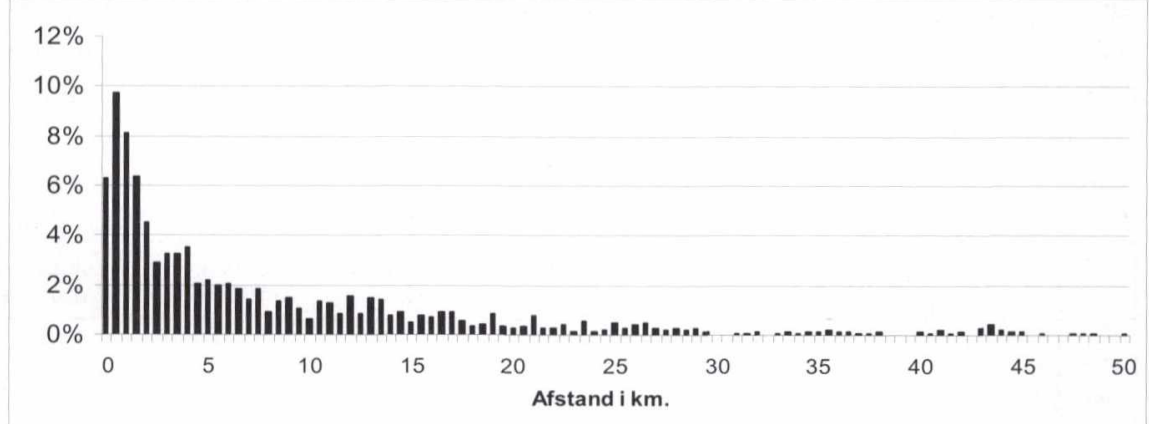

Figur 1c. Kriminalitetsrejser op til $25 \mathrm{~km}$. fordelt efter afstand $i \mathrm{~km} . N=2836$.

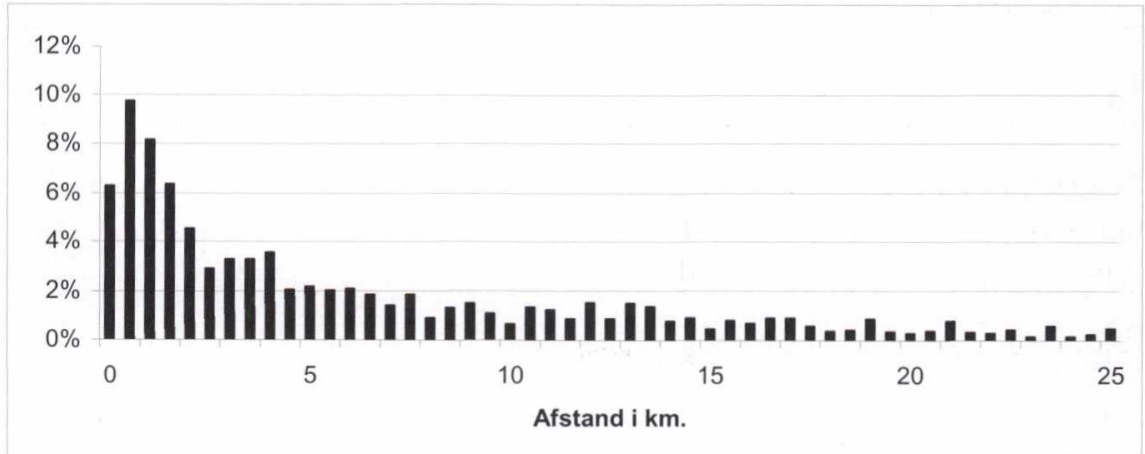

Figur $1 \mathrm{~b}$ er derfor brugt til at afbilde de samme data, men kun for kriminalitetsrejser, der maksimalt er på $50 \mathrm{~km}$. Figuren inkluderer stadig langt størstedelen (94 pct.) af samtlige kriminalitetsrejser. I denne figur bliver bufferzonen omkring lovovertræderens bopæl synlig. Selv denne begrænsede figur giver imidlertid meget lidt information om højre side af fordelingen. Derfor er figur 1c udarbejdet, så det bliver muligt alene at vise de kortere afstande, nemlig de første $25 \mathrm{~km}$. Dette udsnit, der stadig omfatter 88 pct. af alle indbrud, giver den bedste balance mellem detalje og bredde og er derfor brugt i det følgende.

Som nævnt tidligere, er denne overordnede fordeling af danske kriminalitetsrejser i overensstemmelse med de fordelinger, der er fundet i alle større internationale studier. Dvs. at der er en stor andel relativt korte rejseafstande, en bufferzone omkring lovovertræderens bopæl og et fald i antallet af kriminalitetsrejser med stigende afstand fra lovovertræderes hjem. 
Figur 2 viser ligeledes fordelingen af kriminalitetsrejser, men kriminalitetsrejserne er her relateret til gerningsstedets art, dvs. type af beboelse. Af hensyn til sammenligneligheden er beboelsestyperne ordnet efter medianen af den tilbagelagte afstand.

Figur 2. Kriminalitetsrejser fordelt efter type af beboelse m.v.*

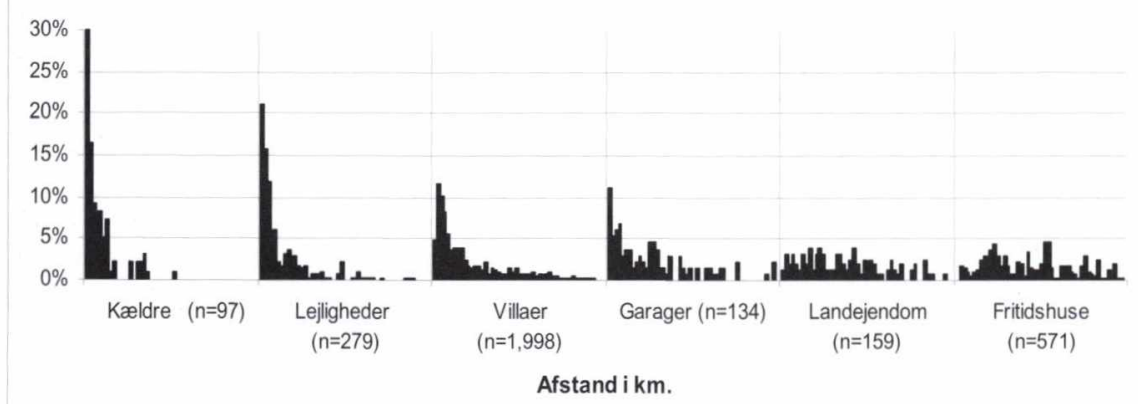

* Figuren viser kun de første $25 \mathrm{~km}$. af hver fordeling.

Mens detaljer er svære at opfatte i figur 2, er det dog samtidig klart, at længden af kriminalitetsrejser afhænger af målets art. Fordelingen af kriminalitetsrejser for villaer ligger nærmest fordelingen for samtlige kriminalitetsrejser (figur 1c), hvilket skyldes, at hovedparten - 62 pct. - af kriminalitetsrejserne er til villaer.

I modsætning til fordelingen af kriminalitetsrejser til villaer viser fordelingerne af kriminalitetsrejser til garager/udhuse, lejligheder og kældre/lofter ingen bufferzone inden for de første $0,5 \mathrm{~km}$. fra lovovertræderens bopæl. Dette er et interessant resultat, som står i kontrast til øvrige studier og til litteraturen, hvor bufferzoner er tæt på at være en kriminologisk konstant.

Kriminalitetsrejser til fritidshuse og landejendomme viser ikke det stærkt aftagende mønster, der er så åbenlyst i fordelingerne af kriminalitetsrejser til andre typer af beboelser. Forskellen mellem disse fordelinger fremgår også af oplysningerne i tabel 1.

Den overordnede fordeling af kriminalitetsrejser er således i bedste fald en ufuldkommen beskrivelse af kriminalitetsrejser til villaer, mens den er misvisende for mønstret for kriminalitetsrejser til alle andre former for beboelser m.v. 
Kriminalitetsrejser til kaldre og lofter

De korteste kriminalitetsrejser er dem til kældre og lofter, idet halvdelen af alle rejser er under $1 \mathrm{~km}$., og meget få er på mere end $5 \mathrm{~km}$., jf. figur 3 .

At rejserne er så korte afspejler utvivlsomt en tendens til, at både kældre og lofter, der udsættes for indbrud, typisk er beliggende i lejlighedskomplekser i tæt beboede områder. Undersøgelsen viser da også, at boligtætheden er størst i de områder, hvor der bliver begået indbrud i kældre/lofter. Undersøgelsen viser endvidere, at aldersmedianen for de lovovertrædere, der begår indbrud i kældre/lofter, er 28 år. Dette kan umiddelbart forekomme overraskende, idet det kunne forventes, at denne form for indbrud primært ville være en form for "drengestreger", altså blive begået af helt unge mennesker. Muligvis er forklaringen på den forholdsvis høje aldersmedian, at indbrud i kældre/lofter er forholdsvis tilfældige lovovertrædelser, der begås af vanskeligt stillede, marginaliserede beboere/naboer, når chancen byder sig. Det er givetvis en form for indbrud, hvor opdagelsesrisikoen typisk vil blive oplevet som ganske lav. Der ses også af figuren, at der ikke findes en bufferzone omkring lovovertræderens hjem.

Figur 3. Kriminalitetsrejser til indbrud i kceldre og lofter $(N=97) *$

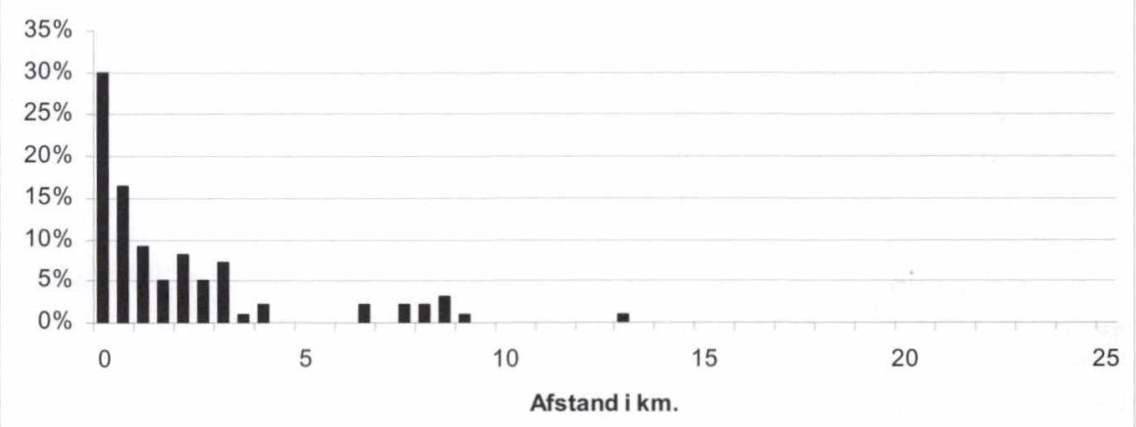

* Figuren viser kun de første $25 \mathrm{~km}$. af fordelingen.

\section{Kriminalitetsrejser til lejligheder}

Eftersom halvdelen af alle kriminalitetsrejser til lejligheder er under 1,3 km., er disse kriminalitetsrejser altså kun en anelse længere end rejserne til kældre/lofter. Dette giver mening, da lejligheder, ligesom kældre/lofter, typisk er placeret i højt urbaniserede områder. Det er imidlertid interessant, at boligtætheden i områder med mange indbrud i lejligheder ikke er nær så stor som dem med mange indbrud i kældre/lofter. Dette kan muligvis skyldes, at kældre og lofter hyppigere forekommer i lejlighedskomplekser i byer og sjældnere i mindre lejlighedsejendomme på landet. 
Det ses af figur 4, at kriminalitetsrejsen til indbrud i lejligheder sjældent er over $5 \mathrm{~km}$. lang. Det sker kun i hvert fjerde tilfælde. Figuren viser videre, at der heller ikke for indbrud i lejligheder synes at være en bufferzone omkring lovovertræderes hjem. Dette er bemærkelsesværdigt, fordi det står i modsætning til mange internationale resultater, som dog ganske er generelle og ikke vedrører specifikke typer af boliger. Det skal muligvis forklares med, at risikoen for genkendelse og den deraf følgende tendens til at søge mål, der ligger lidt væk fra ens egen bolig, ikke i samme grad opleves som væsentlig, når personer bor i tæt befolkede områder (områder med lejlighedskomplekser), som når det drejer sig om områder med mere spredt bebyggelse.

Figur 4. Kriminalitetsrejser til lejligheder $(N=279) *$

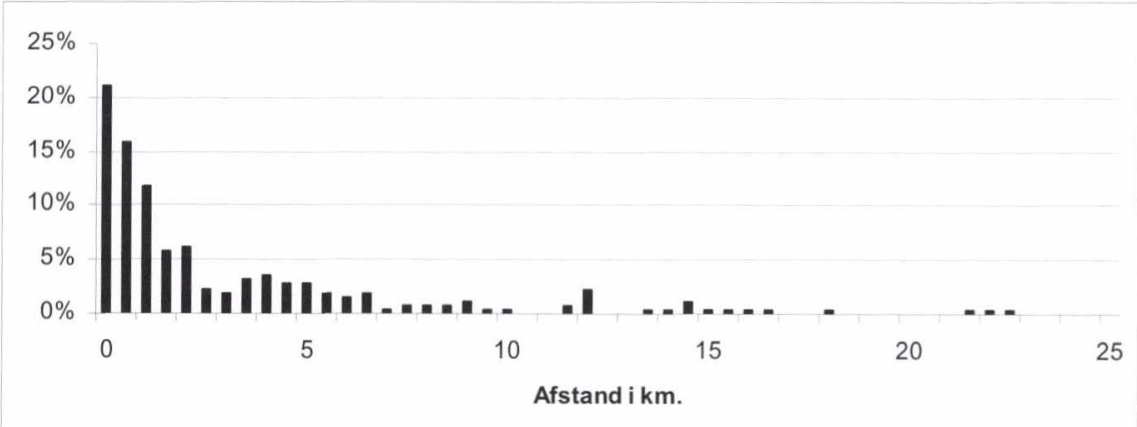

* Figuren illustrerer kun de første $25 \mathrm{~km}$. af fordelingen.

\section{Kriminalitetsrejser til villaer}

Selv om kriminalitetsrejser til indbrud i villaer også er relativt korte (halvdelen er under 3,5 km.), er de dog noget længere end dem til kældre/lofter og lejligheder. Dette følger naturligt af, at villaer ligger mere spredt fordelt og findes i både højt og lavt urbaniserede områder. Medianen for antallet af beboelser per km. ${ }^{2}$ for områder med indbrud i villaer er næsten en fjerdedel af den for indbrud i lejligheder og mere end ni gang så lav som den for indbrud i kældre/lofter. Det anskueliggør den noget ringere kriminalitetsmulighed inden for meget korte afstand i relation til villaindbrud.

Sammenlignet med lovovertrædere, der er sigtet for indbrud i andre typer af beboelser, er villaindbrudstyve i langt flere tilfælde tidligere dømt for indbrud. Det er altså på dette område, man primært finder recidivisterne. Og i modsætning til de tidligere omtalte kriminalitetsrejser er rejser til villaer karakteriseret ved at have en klar og signifikant bufferzone, inden for hvilken lovovertræderne er mindre tilbøjelig til at begå indbrud, jf. figur 5 . 
Figur 5. Kriminalitetsrejser til indbrud $i$ villaer $(N=1998) *$

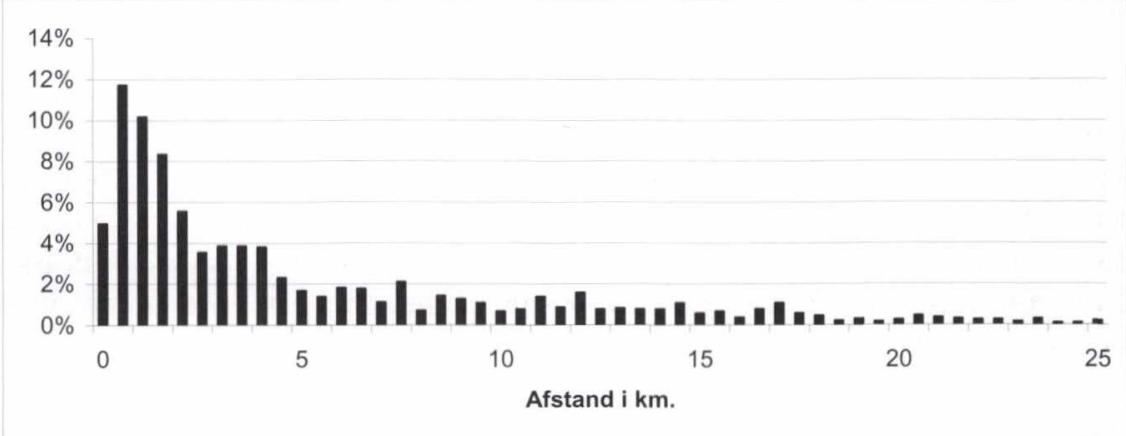

* Figuren viser kun de første $25 \mathrm{~km}$. af fordelingen.

\section{Kriminalitetsrejser til garager/udhuse}

Halvdelen af kriminalitetsrejserne til garager/udhuse er mindre end $6 \mathrm{~km}$., jf. figur 6. Medianen for boligtætheden i de områder, hvor der er begået indbrud i garager/udhuse, er 28/ $\mathrm{km}^{2}$, hvilket svarer ganske godt til den for landejendomme $\left(27 / \mathrm{km}^{2}{ }^{2}\right)$ og fritidshuse $\left(24 / \mathrm{km} .{ }^{2}\right)$, men er noget mindre end den for villaer (95/ $\mathrm{km} .{ }^{2}$ ). Dette tyder på, at villaer med garager/udhuse typisk ligger i landlige omgivelser, og/eller at de garager/udhuse, hvor der var indbrud, hyppigt er tilknyttet landejendomme og fritidshuse.

Med en aldersmedian på 20 år er de individer, der sigtes for indbrud i garager/udhuse, blandt de yngste i undersøgelsen.

Som figur 6 viser, er der tydeligvis ingen bufferzone i relation til denne type indbrud. På den anden side viser figuren også - sammenlignet med de tidligere - at tendensen til afstandsreduktion ("distance decay") er meget mindre. Dette blandede billede kan tænkes at skyldes, at indbrud i garager/udhuse forekommer både i højt urbaniserede områder (hvor boligtætheden reducerer sandsynligheden for en bufferzone) og på landet (hvor en mere udstrakt bufferzone er tænkelig). En anden mulig forklaring er, at der er tale om to typer lovovertrædere på dette område - (1) dem, der opererer meget lokalt uden hensyn til en bufferzone, og (2) dem, der opererer mindre lokalt og mere traditionelt i form af bibeholdelse af en bufferzone. For at teste disse hypoteser er det imidlertid nødvendigt med et større undersøgelsesmateriale, så disse resultater burde under alle omstændigheder foranledige videre forskning, hvor man undersøger spørgsmålet: Afhænger mønstrene for bufferzoner systematisk af lovovertræderens modus operandi eller af målets placering? 
Figur 6. Kriminalitetsrejser til indbrud i garager/udhuse $(N=134)$ *

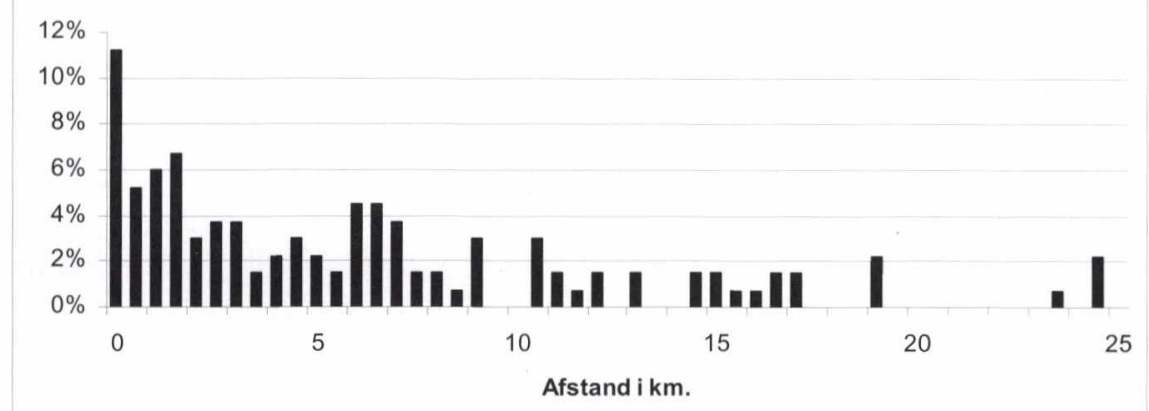

* Figuren viser kun de første $25 \mathrm{~km}$. af fordelingen.

\section{Kriminalitetsrejser til landejendomme}

Med en afstandsmedian på 10,6 km. er den hyppigste kriminalitetsrejse til en landejendom næsten dobbelt så lang som den til garager/udhuse - og det selv om medianen for boligtætheden i områder med indbrud i hhv. landejendomme og garager/udhuse er identiske.

Der er antydninger af en bufferzone for indbrud i landejendomme, jf. figur 7, men derimod ikke findes der ikke en tydelig eller særlig markant afstandsreduktion. Når fordelingen af indbrud også inddrager rejselængder over $25 \mathrm{~km}$., ses derimod tegn på afstandsreduktion.

Figur 7. Kriminalitetsrejser til indbrud i landejendomme ( $N=159)$ *

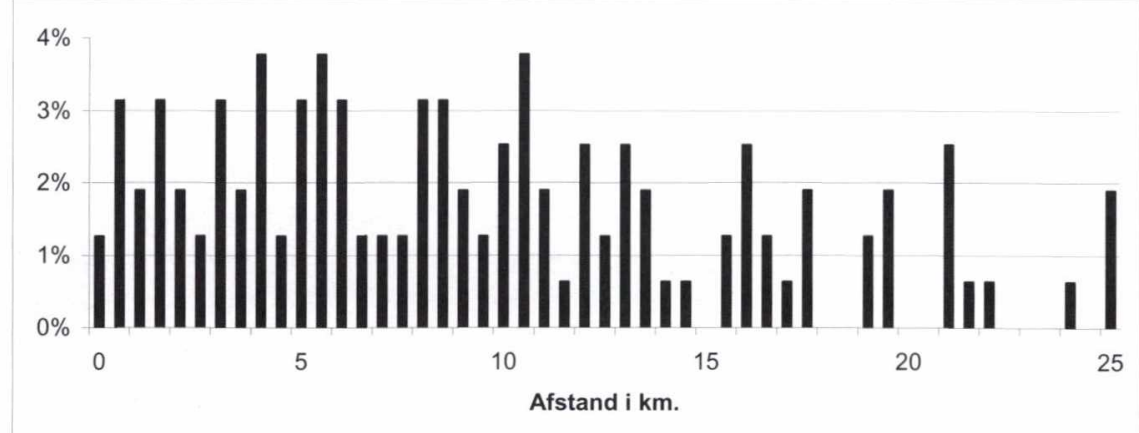

\footnotetext{
* Figuren viser kun de første $25 \mathrm{~km}$. af fordelingen.
} 
Kriminalitetsrejser til fritidshuse

Kriminalitetsrejser til fritidshuse er de længste af alle i denne undersøgelse - med en afstandsmedian på 13,3 km. Dette afspejler utvivlsomt det forhold, at fritidshuse, nærmest per definition, er placeret i landlige omgivelser - en opfattelse som valideres af det faktum, at boligtætheden er lavest for denne kategori af indbrud $\left(24 / \mathrm{km}^{2}{ }^{2}\right)$. Det skal her understreges, at et af de svage punkter ved forskningen i kriminalitetsrejser er, at den baseres på en formodning om, at kriminalitetsrejser i alle tilfælde begynder ved en lovovertræders hjem. Denne formodning behøver, især når det angår indbrud i fritidshuse, imidlertid ikke altid at være korrekt, jf. også det følgende.

Aldersmedianen for dem, der begår indbrud i fritidshuse, er på kun 19 år - den laveste median i datamaterialet. Dette kan muligvis skyldes, at et antal af disse forbrydelser begås af unge, der keder sig, når de er på ferie med deres forældre. Samtidig er dog andelen af højfrekvente lovovertrædere blandt indbrudstyve i fritidshuse stor, idet de i gennemsnittet er sigtet for 12 indbrudstyverier inden for den undersøgte periode.

Kriminalitetsrejser til fritidshuse er desuden karakteriseret ved, at der i mange flere tilfælde end ved de andre former for indbrud er medskyldige. Det er velkendt, at hyppigheden af medskyldige samvarierer med alder, idet det primært er unge lovovertrædere, der begår kriminalitet sammen med andre (Reiss 1988). ${ }^{4}$ Det siger sig selv, at forbrydelser, der involverer medskyldige, kan hyppigere kan indebære længere rejser, idet fx den hovedansvarlige kan tænkes at kende gerningsstedet, men rekruttere medskyldige, som bor andetsteds. På samme måde kan lovovertrædere, som besøger bekendte langt fra hjemmet, også bidrage til, at kriminalitetsrejser til indbrud i fritidshuse er karakteriseret ved at være lange. Den store andel højfrekvente lovovertrædere kan dog også tyde på, at der blandt dem, der begår indbrud i fritidshuse, er en del mere professionelle indbrudstyve, som bevidst søger til afsides liggende områder for i fred og ro at kunne tømme huse for værdigenstande.

Der eksisterer en meget tydelig bufferzone, for så vidt angår indbrud i fritidshuse, jf. figur 8, hvilket dog givetvis skal forklares med, at kun få har en bopælsadresse i et sommerhusområde. Figuren viser ikke en klar afstandsreduktion, men denne bliver dog lidt tydelig, hvis også rejser over $25 \mathrm{~km}$. inddrages $i$ analysen. Selv her er fordelingen imidlertid noget sporadisk på trods af det relativt store antal sager $(\mathrm{N}=571)$. 
Figur 8. Kriminalitetsrejser til fritidshuse $(N=571)^{*}$

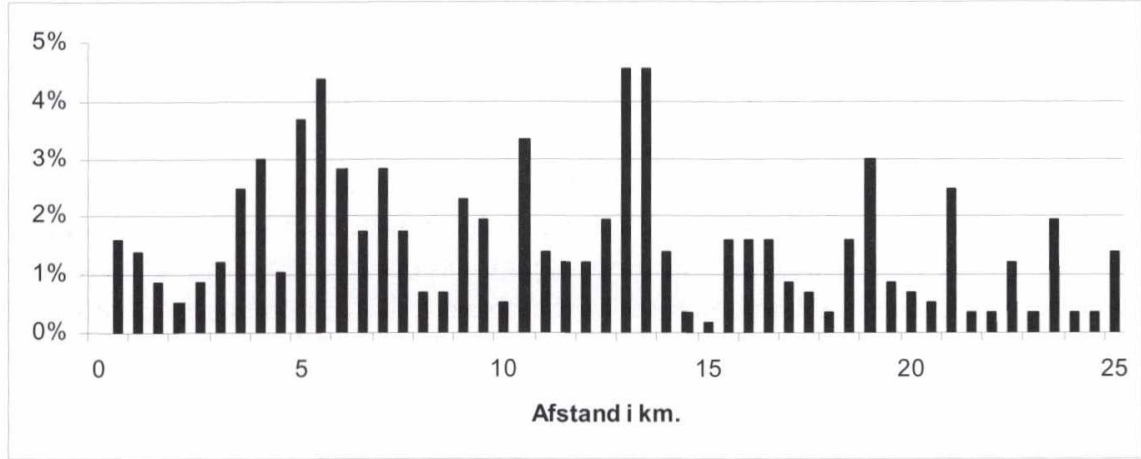

* Figuren viser kun de første $25 \mathrm{~km}$. af fordelingen.

\section{Søger indbrudstyve deres mål i velhaverkvarterer?}

Rational choice teori (Cornish og Clarke 1986) indtager det neo-klassiske synspunkt, at beslutningen om at begå en bestemt forbrydelse er et resultat af en rational beregning af de opfattede omkostninger og fordele ved at handle på en bestemt måde i en specifik kontekst. Videre antages omkostninger og fordele at afspejle lovovertræderens samlede vurdering af følgende tre aspekter ved handlingen/lovovertrædelsen: risiko, indsats (anstrengelse) og belønning. Mens mere positivistisk orienterede sociologer pointerer, at rationaliteten må betragtes som yderst begrænset og indsnævret af en mængde biologiske, psykologiske og/eller sociologiske faktorer, er idéen om, at en form for (ufuldkommen) rationalitet styrer lovovertræderes beslutningsproces, blevet mere fremtrædende (se fx Cornish og Clarke 1986; Felson 1998; Gottfredson og Hirschi 1990; Wilson og Hernstein 1985).

I det følgende vil det blive belyst, i hvilken udstrækning indbrudstyve rejser til velhaverkvarterer i deres søgen efter lukrative mål. Forestillingen om, at det forholder sig på den måde, tyder implicit på tiltro til en rationel beslutningsproces. Rationalitetssynspunktet indebærer imidlertid også, at lange kriminalitetsrejser ikke nødvendigvis er attraktive for indbrudstyve. Mens ønsket om at maksimere belønningen kan øge sandsynligheden for at rejse langt for at nå målet, vil den indsats eller de anstrengelser, den længere rejse indebærer, omvendt mindske den. Ligeledes vil risiciene ved at begå indbrud tæt på hjemmet kunne fremme ønsket om i hvert fald at foretage en mindre rejse, mens manglen på kendskab til områder uden for ens eget "fortrolighedsrum" taler imod det. En indbrudstyvs opfattelse af den potentielle risiko, indsats og belønning, der er forbundet med kriminalitetsrejser, er sandsynligvis påvirket af hans eller hendes professionalisme. Både forskning og common sense tyder på, at "professionelle" rejser længere end amatører. Men hvor stor en del af indbrudstyve kan betegnes som professionelle? 
Det er et spørgsmål, der længe har optaget forskere. Weisel (2002) har redegjort for litteraturen (primært den anglo-amerikanske) på området og konkluderer, at den største andel af indbrudstyvene er "amatører" - en gruppe, som sammenlignet med "professionelle" er karakteriseret ved at være yngre, mindre mobile, lettere at afskrække med hunde, låse og alarmer og mindre fremgangsrige med hensyn til udbytte, afsætning af varer og undvigelse af opdagelse. Professionelle er altså - ud over at være ældre og mere mobile i deres søgen efter et mål - også mindre tilbøjelige til at blive generet af hindringer og bedre til at få omsat effekterne. En væsentlig forskel mellem amatører og professionelle angår netop sidstnævnte. Mens amatører er tvunget til at opsøge købere, har professionelle hyppigere et veletablerede kundenetværk (Weisel 2002, 16).

Denne fremstilling stemmer (relativt) godt overens med beskrivelsen af fire prototyper af indbrudstyve, som er beskrevet på det Danske Kriminalpræventive Råds (2005) hjemmeside. To af typerne er udpræget amatøragtige, mens de øvrige er hhv. semiprofessionelle og professionelle.

Ifølge rådet er den største gruppe af indbrudstyve i Danmark stofmisbrugere, som antages at være ansvarlige for 75 pct. af alle indbrud i de store byer. Mange af disse indbrudstyve er i starten af 20'erne, kommer typisk til deres mål til fods og går generelt efter kontanter og andre let håndterlige ting (smykker, cd'ere m.v.), som også er lette at komme af med. Gruppen betegnes som ikkeprofessionelle.

Den anden gruppe af ikke-professionelle er "lømler" i teenagealderen, som begår indbrud for sjov og for spændingens skyld. Gruppen går primært efter kontanter, spiritus og pc/stereoudstyr, som de gerne selv beholder.

Den gruppe, som af rådet beskrives som semi-professionelle, består af personer, der er tilknyttet bikerklubber som fx Hells Angels. Mens disse personer har visse ligheder med den fjerde gruppe, de professionelle, beskrives deres metoder dog som grovere og mindre finesseprægede, og deres mål er ting, der er lette at sælge, men generelt mindre værdifulde.

Endelig er der gruppen af "professionelle", der beskrives som planlæggere, der søger stor profit og derfor også sjældnere er "på arbejde". Det drejer sig om voksne mænd, typisk af dansk herkomst, som har været involveret i kriminalitet $i$ mange år og har etableret et netværk af købere til deres stjålne varer. Disse professionelle foretrækker brugen af hurtige, lukkede lastvogne som arbejdskøretøjer, da de kan rumme mange og store genstande, fx B\&O udstyr, arkitekttegnede møbler og kunsthåndværk. Professionelle er overvejende selektive i deres valg af mål, og de foretrækker dyre villaer, som de ofte overvåger, inden de bryder ind. De udnytter specifikke redskaber til specifikke jobs og ved, hvordan man håndterer alarmsystemer. 
Rådet oplyser intet om størrelsesordenen af denne gruppe af professionelle eller af de semiprofessionelle, men ud fra vurderingen af omfanget af stofmisbrugende indbrudstyve og af unge "lømler" må det dog antages, at de semiprofessionelle og de professionelle kun kan være ansvarlige for en lille, om end måske ganske værdifuld, andel af alle indbrud. ${ }^{5}$

Det skal tilføjes, at den typologi, Det Kriminalpræventive Råd har udarbejdet for indbrudstyve, ikke er baseret på videnskabelige undersøgelser, men på skøn baseret på erfaringer.

Som nævnt skal der her ses på, i hvilken udstrækning indbrudstyve især udsøger sig velhaverområder. Dette gøres ved at sammenligne den gennemsnitlige husstandsindkomst for de postnummerzoner, hvori indbrudstyve bor, med den gennemsnitlige husstandsindkomst i de postnummerzoner, hvor deres ofre bor.

Ifølge data fra Danmarks Statistik har postnummerzonen, der vedrører den naturskønne Sejerø, den laveste gennemsnitlige husstandsindkomst i Danmark, mens postnummerzonen for Rungsted Kyst i Nordsjælland har den højeste. Det fulde spektrum af gennemsnitlige indkomster i Danmarks postnummerzoner spænder fra $243.000 \mathrm{kr}$. til $886.000 \mathrm{kr}$. med en median på $390.000 \mathrm{kr}$.

Tabel 2 viser andelen af ofrene og andelen af lovovertrædere, som henhører under den tredjedel af postnummerzonerne, som har hhv. den laveste, den mellemste og den højeste husstandsindkomst. Denne indkomstkategorisering er baseret på nationale data fra Danmarks Statistik.

Tabel 2. Lovovertradere og ofre fordelt efter den gennemsnitlige husstandsindkomst $i$ deres postnummerzone. Alle typer af indbrud.

\begin{tabular}{|l|c|c|c|c|}
\hline & N & Laveste & Mellemste & Højeste \\
\hline Ofre & 3238 & $53 \%$ & $23 \%$ & $25 \%$ \\
\hline Lovovertrædere & 3238 & $64 \%$ & $18 \%$ & $17 \%$ \\
\hline
\end{tabular}

Umiddelbart vurderet, er det bemærkelsesværdigt, at mere end halvdelen af både ofrene og lovovertræderne kommer fra lave indkomstkategori. Dette beror imidlertid på, at en stor del af indbrudstyverierne begås inden for samme postnummerzone, som lovovertræderen bor i, og at indbrudstyve - næppe overraskende - hyppigt bor i de mindre velhavende områder.

En tilsvarende opgørelse for alene kriminalitetsrejser til villaer viser et tilsvarende mønster.

Der er ikke i undersøgelsen fundet bevis for, at kriminalitetsrejsens længde er afhængig af indkomstniveauet i de områder, hvor lovovertræderen bor i. Med udgangspunkt $i$ antagelsen om, at indbrudstyve primært søger til de mere velhavende kvarterer, måtte man således forvente, at indbrudstyve, der bor i de økonomisk 
ringest stillede områder, ville rejse længere end dem, der bor i rigere områder - altså en økonomisk betinget mobilitet. Undersøgelsen viser imidlertid, at medianen for afstanden til indbrud er nogenlunde den samme for lovovertrædere, der bor i områder med hhv. lave, mellem og høje indkomster (4,5, 5,2 og 5,1 km.). Kriminalitetsrejser, der starter i lave indkomstområder, er faktisk en anelse kortere end dem, der begynder i de mellemste og højeste indkomstområder.

Den tilbagelagte afstand er derimod stærkt afhængig af, hvilken indkomstgruppe offeret tilhører, jf. figur 9. Mens afstandsmedianen for de 1700 kriminalitetsrejser til ofre i lave indkomstområder er 3,5 km., er den for de 797 kriminalitetsrejser til ofre i høje indkomstområder $6,6 \mathrm{~km}$. Jo højere indkomstgrupperinger, man ser på, desto større er forskellen i den fundne afstand. For eksempel er afstandsmedianen for de 102 kriminalitetsrejser til de ti fattigste postnummerzoner kun $1,3 \mathrm{~km}$., mens de $88 \mathrm{kriminalitetsrejser} \mathrm{til} \mathrm{de} \mathrm{ti} \mathrm{rigeste} \mathrm{postnummerzoner} \mathrm{har}$ en afstandsmedian på $14,5 \mathrm{~km}$.

Figur 9. Afstandsmedian ( $\mathrm{km}$.) efter offers indkomstområde $(N=3238)$

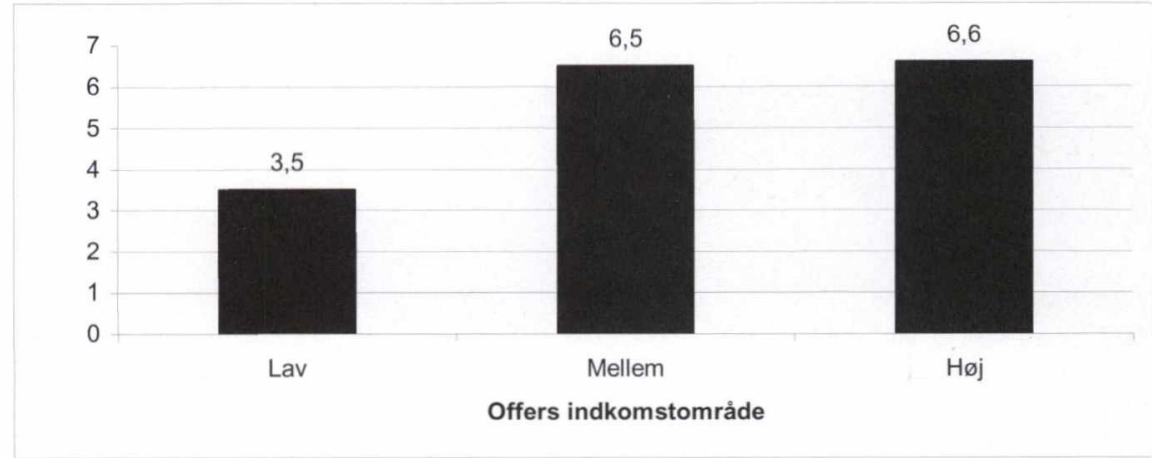

Det er imidlertid de færreste indbrudstyve, der anstrenger sig meget og foretager en længere rejse for at nå til målet. De fleste bliver i deres eget område eller tager til områder, der økonomisk ligner dem, de kommer fra. Selv blandt de 1705 kriminalitetsrejser, hvor lovovertræderen krydser en eller flere postnummergrænser for at komme til målet, lader det til, at lovovertrædere foretrækker områder, der minder om dem, hvori de selv bor. Dette er illustreret i figur 10, der alene omfatter denne del af kriminalitetsrejserne. I de forholdsvis få tilfælde, hvor indbrudstyve fra lave indkomstområder krydser ind i højere indkomstområder, sker det først og fremmest til områder med de mellemste indkomster og sjældent til områder med de højeste indkomster. Lovovertrædere fra de højeste indkomstområder begår på den anden side i lige stort omfang indbrud i de mellemste og de laveste indkomstområder. 
Figur 10. Fordeling af kriminalitetsrejser til lave, mellem og høje indkomstområder efter lovovertrcederens indkomstområde $(N=1705) *$

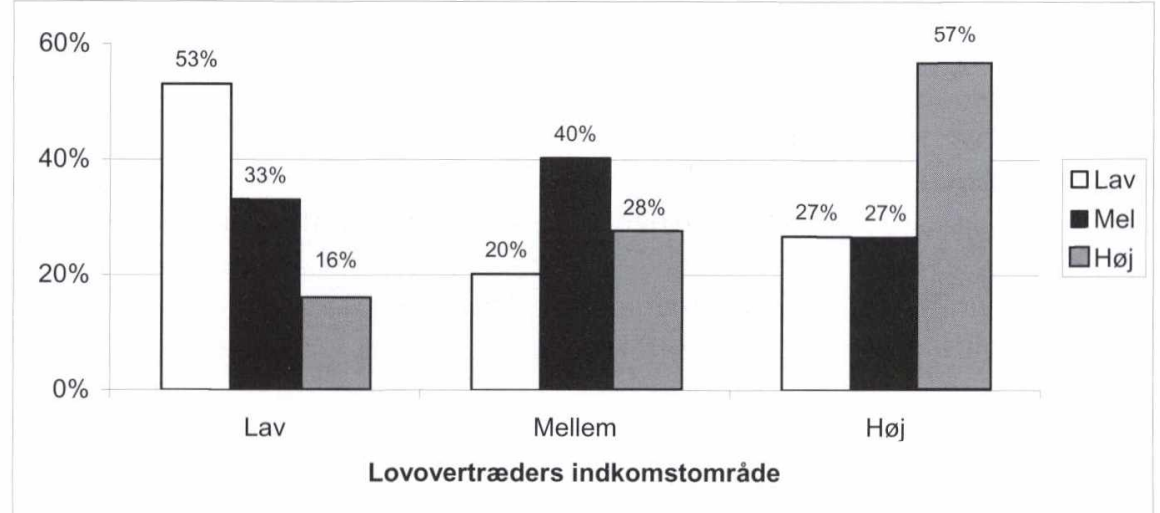

* Omfatter kun kriminalitetsrejser, hvor lovovertræderen krydser en eller flere postnummergrænser.

Jeg har som nævnt ønsket at undersøge holdbarheden af den populære antagelse, at indbrudstyve foretrækker de velhavende områder, når de søger efter et mål for deres forbrydelse. Der er ikke tvivl om, at nogle indbrudstyve opererer på denne måde, men undersøgelsesmaterialet viser samtidig klart, at det snarere er undtagelsen end reglen.

\section{Litteraturliste}

Baldwin, John, and Anthony E. Bottoms. 1976. The Urban Criminal: A Study in Sheffield. London: Tavistock Publications.

Brantingham, Paul J., and Patricia L. Brantingham. 1981. Notes on the geometry of crime. In P.J. Brantingham \& P.L. Brantingham (Eds.), Environmental criminology. Beverly Hills, CA: Sage.

Cornish, Derek B., and Ronald V. Clarke. 1986. The Reasoning Criminal: Rational Choice Perspectives on Offending. New York, NY: Springer-Verlag.

Danish Crime Prevention Council (Det Kriminalpræventiv Råd). 2005. "De typiske tyve (The typical thieves). Accessed June 12, 2005, at: www.stopindbrud. $\mathrm{dk} /$ Default.asp? ID $=622$

Felson, Marcus. 1998. Crime and Everyday Life, $2^{\text {nd }}$ Ed. Thousand Oaks, California: Pine Forge Press.

Gottfredson, Michael R., and Travis Hirschi. 1990. A General Theory of Crime. Stanford. Standford Univeristy Press.

Pope, C.E. 1980. Patterns in burglary: An empirical examination of offense and offender characteristics. Journal of Criminal Justice 8 (1):39-51. 
Pyle, Gerald .F. 1974. The Spatial Dynamics of Crime. Research Paper No. 159. Chicago: Department of Geography, University of Chicago.

Reiss, Albert J., Jr. 1988. "Co-offending and criminal careers." In Michael Tonry and Norval Morris (eds.) Crime and Justice, Vol. 10, pp. 117-170. Chicago: University of Chicago Press.

Repetto, Thomas A. 1974. Residential Crime. Cambridge, MA: Ballinger.

Weisel, Deborah Lamm. 2002. Burglary of Single-Family Houses. Washington, D.C: U.S. Department of Justice, Office of Community Oriented Policing Services.

White, R. Clyde. (1932). The relation of felonies to environmental factors in Indianapolis. Social Forces, 10, 498-509.

Wilson, James Q. and Richard Herrnstein. 1985. Crime and Human Nature. New York: Simon and Schuster.

\section{Noter:}

1 Undersøgelsen, der er finansieret af midler fra Justitsministeriets Forskningspulje, er i sin helhed tilgængelig på Justitsministeriets hjemmeside, www.jm.dk, under titlen "Journey to Danish Burglary".

2 POLMAP-data er identisk med de data, der er tilgængelige i POLSAS, bortset fra at POLMAP tilføjer geografiske koordinater for lovovertræderens bopæl og gerningsstedet, således at disse data kan undersøges ved at benytte GIS software.

3 Danmarks statistik har givet oplysninger om 591 postnumre. Informationen om postnumre fra tæt beboede områder, København K, Vesterbro og Frederiksberg C, er angivet i intervaller på 100. Fx er postnumrene i København K opdelt i fem grupper: postnummer 1000-1099, 1100$1199,1200-1299,1300-1399$ og 1400-1499. Det areal, de danske postnumre dækker, varierer i størrelse fra 0,3 til $450 \mathrm{~km}^{2}$ med et gennemsnit og en median på hhv. 73,2 og 48,8 km. ${ }^{2}$. Lovovertræderne i denne undersøgelse kommer fra postnumre, hvis arealer har et gennemsnit og en median størrelse på hhv. $129,3 \mathrm{og} 83,6 \mathrm{~km} .{ }^{2}$.

$4 \quad$ I data vedrørende alle former for indbrud har omfanget af medskyldige en Spearman korrelation på $\mathrm{Rho}=-0,33(\mathrm{p}<0.0001 ; \mathrm{N}=3238)$ med lovovertræders alder.

5 Desværre indeholder POLSAS/POLMAP ikke i dag systematisk oplysninger om modus operandi og arten af de stjålne varer - information som antagelig kunne bruges til at identificere professionelle indbrudstyve. Der findes dog i POLSAS/POLMAP tre variabler, der er relateret til modus operandi og typen af stjålne varer, men disse felter er blanke i mere end 97 pct. af alle rapporterede indbrud.

\section{Adresse:}

Forskningsafdeling III

Det juridiske Fakultet, Københavns Universitet

Sankt Peders Stræde 19

DK - 1453 Copenhagen K

Dave.Sorensen@jur.ku.dk 